\title{
Ammonia synthesis at low temperatures
}

\author{
Rod, Thomas Holm; Logadottir, Ashildur; Nørskov, Jens Kehlet
}

Published in:

Journal of Chemical Physics

Link to article, DOI:

10.1063/1.481103

Publication date:

2000

Document Version

Publisher's PDF, also known as Version of record

Link back to DTU Orbit

Citation (APA):

Rod, T. H., Logadottir, A., \& Nørskov, J. K. (2000). Ammonia synthesis at low temperatures. Journal of Chemical Physics, 112(12), 5343-5347. https://doi.org/10.1063/1.481103

\section{General rights}

Copyright and moral rights for the publications made accessible in the public portal are retained by the authors and/or other copyright owners and it is a condition of accessing publications that users recognise and abide by the legal requirements associated with these rights.

- Users may download and print one copy of any publication from the public portal for the purpose of private study or research.

- You may not further distribute the material or use it for any profit-making activity or commercial gain

- You may freely distribute the URL identifying the publication in the public portal

If you believe that this document breaches copyright please contact us providing details, and we will remove access to the work immediately and investigate your claim. 


\title{
Ammonia synthesis at low temperatures
}

\author{
T. H. Rod, A. Logadottir, and J. K. Nørskov ${ }^{\text {a) }}$ \\ Center for Atomic-scale Materials Physics, Department of Physics, Technical University of Denmark, \\ DK-2800 Lyngby, Denmark
}

(Received 16 December 1999; accepted 20 December 1999)

\begin{abstract}
Density functional theory (DFT) calculations of reaction paths and energies for the industrial and the biological catalytic ammonia synthesis processes are compared. The industrial catalyst is modeled by a ruthenium surface, while the active part of the enzyme is modeled by a $\mathrm{MoFe}_{6} \mathrm{~S}_{9}$ complex. In contrast to the biological process, the industrial process requires high temperatures and pressures to proceed, and an explanation of this important difference is discussed. The possibility of a metal surface catalyzed process running at low temperatures and pressures is addressed, and DFT calculations have been carried out to evaluate its feasibility. The calculations suggest that it might be possible to catalytically produce ammonia from molecular nitrogen at low temperatures and pressures, in particular if energy is fed into the process electrochemically. (C) 2000 American Institute of Physics. [S0021-9606(00)70911-1]
\end{abstract}

\section{INTRODUCTION}

The conversion of $\mathrm{N}_{2}$ from the atmosphere into a biologically accessible form of nitrogen is a very difficult process. The formation of, e.g., $\mathrm{NH}_{3}$ requires the $\mathrm{N}-\mathrm{N}$ bond to be broken, and this bond is extremely strong, the bond energy being about $1000 \mathrm{~kJ} / \mathrm{mole}$. The process, therefore, requires either extreme temperatures, like in an arc, or the participation of an effective catalyst. Ammonia is synthesized from $\mathrm{N}_{2}$ by two very different catalytic process. Industrially it takes place by passing $\mathrm{N}_{2}$ and $\mathrm{H}_{2}$ over Fe or Ru surfaces at quite high temperatures and pressures, about $400{ }^{\circ} \mathrm{C}$ and 100 atm. ${ }^{1,2}$ In nature, on the other hand, the enzyme nitrogenase catalyzes the synthesis of ammonia from $\mathrm{N}_{2}$, electrons, and protons at room temperature and atmospheric pressure. ${ }^{3,4}$

In the present paper we discuss why the two processes require such different reaction conditions, and whether a process similar to the biological one can be envisioned at a metal surface. We base the discussion on new insight into the molecular mechanisms of the two processes from experiments and from density functional calculations of the reaction energetics. The calculations suggest that a low temperature, low pressure process might be possible on a metal surface under certain conditions.

\section{THE SURFACE PROCESS}

The ammonia synthesis reaction,

$\mathrm{N}_{2}+3 \mathrm{H}_{2} \rightleftharpoons 2 \mathrm{NH}_{3}$,

on $\mathrm{Fe}$ and $\mathrm{Ru}$ surfaces has been the subject of a large number of experimental and theoretical studies and a detailed, molecular picture of the process has been developed..$^{5-17}$ The reaction proceeds via dissociation of $\mathrm{N}_{2}$ and $\mathrm{H}_{2}$ on the surface with subsequent hydrogenation of the adsorbed $\mathrm{N}$ atoms. Our density functional theory (DFT) calculations of the reaction energetics on $\mathrm{Ru}$ surfaces illustrate the reaction

${ }^{a)}$ Electronic mail: norskov@fysik.dtu.dk mechanism, see Fig. 1. The dissociation of $\mathrm{N}_{2}$ is the rate limiting step in this reaction. The barrier for dissociation is rather low; experiments find a dissociation barrier close to zero on Fe surfaces ${ }^{7,8}$ and as low as $40 \mathrm{~kJ} / \mathrm{mole}$ on stepped Ru. ${ }^{9}$ Both values are consistent with the temperature dependence of the synthesis rate measured on an industrial catalyst. ${ }^{10-15}$ They are also in excellent agreement with reaction barriers calculated using DFT. ${ }^{9,16}$ The high temperatures and pressures are, therefore, not needed for $\mathrm{N}_{2}$ dissociation to take place. $\mathrm{H}_{2}$ dissociation is even more facile. ${ }^{10,17}$ The problem in the surface process is that the bonding of the $\mathrm{N}$ and $\mathrm{H}$ atoms to the metal surfaces is so strong (cf. Fig. 1) that high temperatures are needed to have enough clean, reactive surface available for dissociation and reaction. ${ }^{12,13}$ The high temperature has the side effect that the equilibrium in Eq. (1) is shifted to the left. This is not desirable, since no catalyst can produce more ammonia than the equilibrium amount. The high pressures are chosen to alleviate this problem, since that shifts the equilibrium back towards the products again.

A low temperature process based on $\mathrm{N}_{2}$ and $\mathrm{H}_{2}$ dissociation on the catalyst surface would, therefore, require a surface which does not bind the $\mathrm{N}$ and $\mathrm{H}$ atoms too strongly while keeping the barrier for $\mathrm{N}_{2}$ dissociation low. Ru may be a slightly better catalyst than Fe because it does that to some extent, but a really good, low temperature catalyst based on the reaction Eq. (1) may be hard to find because the $\mathrm{N}$-surface bond strength and the barrier for $\mathrm{N}_{2}$ dissociation tends to be strongly coupled so that a weaker $\mathrm{N}$-surface bond also results in a higher dissociation barrier. ${ }^{18,19}$

\section{THE ENZYME PROCESS}

The enzyme nitrogenase represents an alternative catalyst for the ammonia synthesis. The active part in the enzyme is believed to be the FeMo cofactor (FeMoco) which has the stoichiometric formula $\mathrm{MoFe}_{7} \mathrm{~S}_{9}$ (homo-citrate). The overall process can be written 


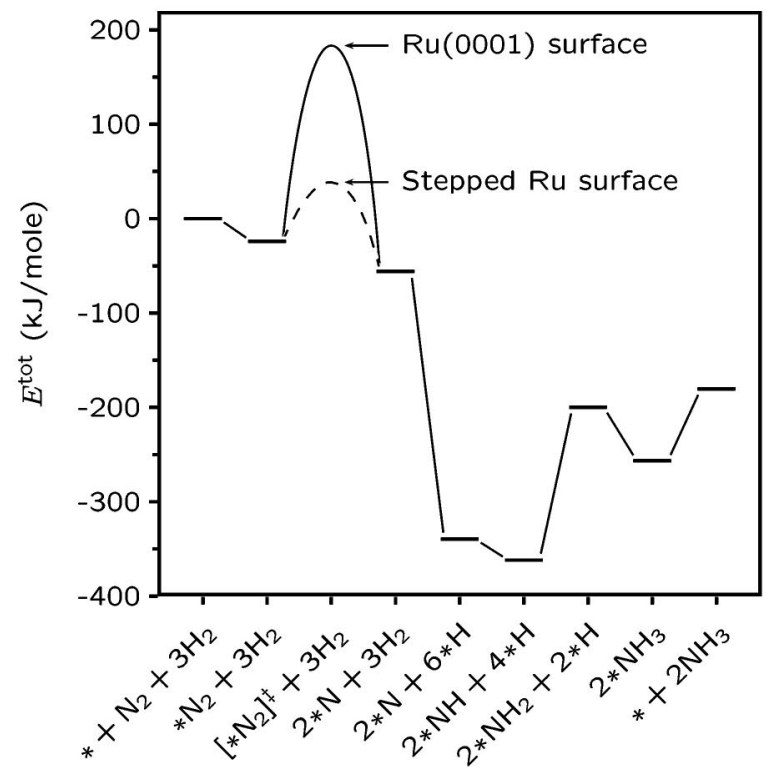

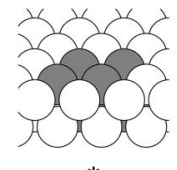

*

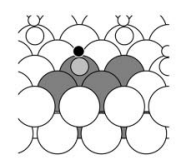

$* \mathrm{NH}$

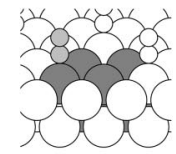

$* \mathrm{~N}_{2}$

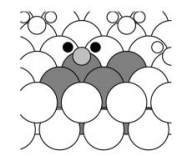

$* \mathrm{NH}_{2}$

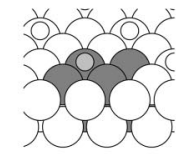

$* \mathrm{~N}$

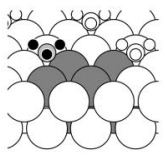

$* \mathrm{NH}_{3}$
FIG. 1. Energy diagram for ammonia synthesis on $\mathrm{Ru}(0001)$. In the top panel the calculated energies for intermediates of the ammonia synthesis on $\mathrm{Ru}(0001)$ are shown, together with the calculated barriers for $\mathrm{N}_{2}$ dissociation on a $\mathrm{Ru}(0001)$ surface and on stepped $\mathrm{Ru}$ surface. For the barrier see Ref. 9 for further details. The binding energy is defined relative to the energies of the free $\mathrm{Ru}(0001)$ surface $(*)$, and the gas phase molecules $\mathrm{N}_{2(g)}$, and $\mathrm{H}_{2(g)}$ by $E^{\mathrm{tot}}=E(X)-E(*)-E\left(\mathrm{~N}_{2(g)}\right)-3 E\left(\mathrm{H}_{2(g)}\right)$, where $X$ denotes the species shown along the horizontal axis. Structures of the most stable intermediates are shown below the energy diagram. One super cell is gray toned such that $\mathrm{Ru}$ is medium gray, $\mathrm{N}$ is light gray, and $\mathrm{H}$ is black.

$$
\mathrm{N}_{2}+6 e^{-}+6 \mathrm{H}^{+} \rightleftharpoons 2 \mathrm{NH}_{3},
$$

where the obligatory simultaneous $\mathrm{H}_{2}$ evolution has been left out. The electrons are provided by reduced ferredoxin. Large amounts of energy is used in the process, both in the form of a high chemical potential of the electrons and in the form of hydrolysis of at least 16 molecules adenosinetriphosphate (ATP) per turn over of Eq. (2).,

The active site of the enzyme is very well characterized, ${ }^{20-32}$ but the detailed molecular mechanism is not as well established as for the metal surface process. It is generally believed that the biological process does not involve initial breaking of the $\mathrm{N}-\mathrm{N}$ bond, ${ }^{33}$ and recent DFT calculations on different $\mathrm{Mo}, \mathrm{Fe}$ sulfide complexes modeling the FeMoco ${ }^{34-36}$ support this picture. These are the same type of calculations, ${ }^{9,16}$ describing in detail the experimentally very well characterized surface process. It is, therefore, likely that the approach can be used to describe the enzyme process as well. Here the main approximation is that only a small fraction of the enzyme can be included. DFT calcula-
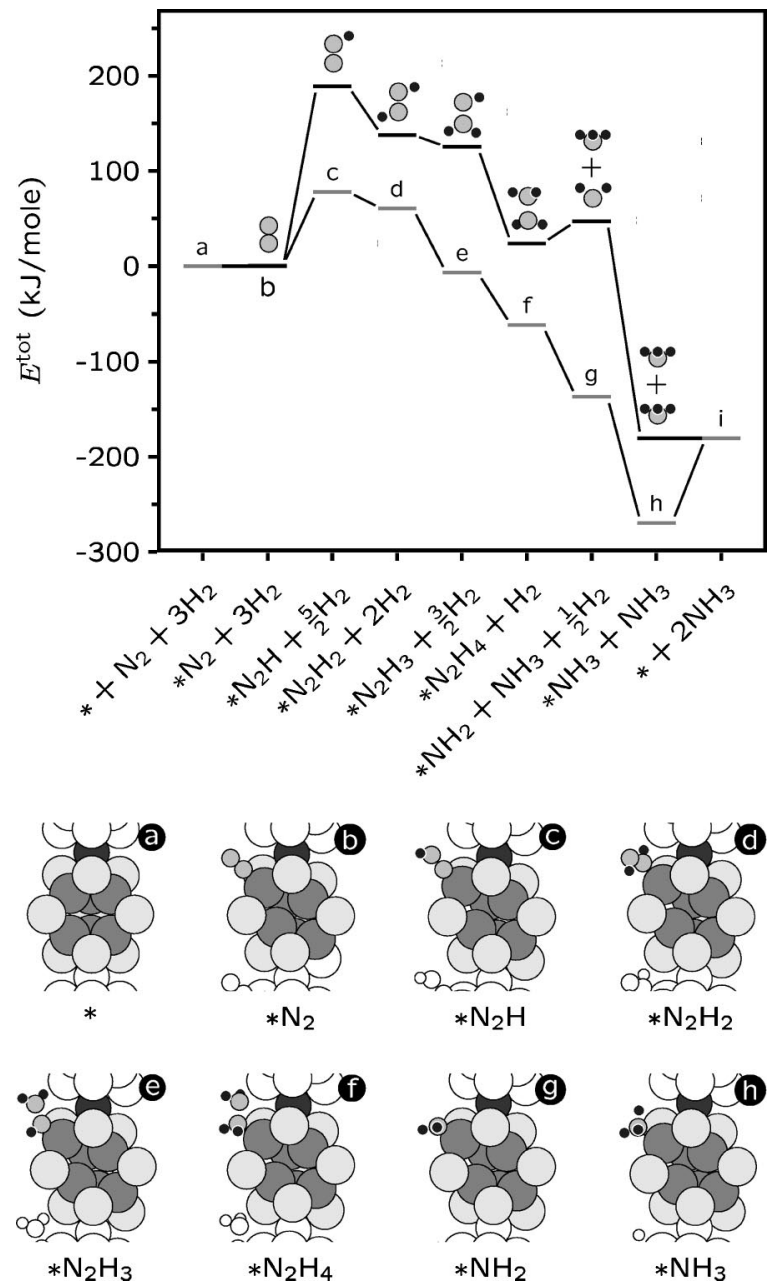

FIG. 2. Energy diagram for the hydrogenation of $\mathrm{N}_{2}$ in the gas phase and on the $\mathrm{MoFe}_{6} \mathrm{~S}_{9}$ complex modeling the FeMoco. In the top panel the calculated binding energies of the most stable intermediates along the reaction path for hydrogenation of $\mathrm{N}_{2}$ on the $\mathrm{MoFe}_{6} \mathrm{~S}_{9}$ complex (gray bars) and in the gas phase (black bars) are plotted. The binding energy, $E^{\text {tot }}$, defined in Fig. 1, is relative to the gas phase molecules $\mathrm{N}_{2(g)}$ and $\mathrm{H}_{2(g)}$. The asterisk along the horizontal axis denotes either the $\mathrm{MoFe}_{6} \mathrm{~S}_{9}$ complex in case of the gray bars or vacuum in case of the black bars. The labels of the gray bars refer to the most stable intermediates of the complex shown below the energy diagram with one super cell gray toned. The gas phase structures are shown immediately above the corresponding black energy bars. The calculations for the gas phase is in reasonable agreement with Refs. 35 and 56 and references therein. One super cell is gray toned with the key: Light gray large circles: $\mathrm{S}$; medium gray: Fe; dark gray: Mo; light gray small circles: $\mathrm{N}$; and black: $\mathrm{H}$.

tions using a $\mathrm{MoFe}_{6} \mathrm{~S}_{9}$ complex to model the FeMoco suggest that $\mathrm{N}_{2}$ is adsorbed on the FeMoco without dissociating, and when electrons and protons are added to the $\mathrm{N}_{2}$ molecule one by one, first one and then the second $\mathrm{NH}_{3}$ molecule (or $\mathrm{NH}_{4}^{+}$ion) leaves the catalytic site. ${ }^{36}$ Figure 2 compares the energetics of adding $\mathrm{H}$ atoms (from $\mathrm{H}_{2}$ ) to an $\mathrm{N}_{2}$ molecule in the gas phase and adsorbed on the $\mathrm{MoFe}_{6} \mathrm{~S}_{9}$ complex. The effect of the $\mathrm{MoFe}_{6} \mathrm{~S}_{9}$ complex is very significant, in particular in stabilizing the least stable NNH intermediate by 110 $\mathrm{kJ} / \mathrm{mole}$.

The calculated energetics, Fig. 2, suggests that if the hydrogen entering the process comes directly from $\mathrm{H}_{2}$, the model enzyme still has a sizeable "barrier" associated with the $\mathrm{NNH}$ intermediate. In the biological process $\mathrm{H}_{2}$ is not the 
source of hydrogen atoms, and the energy of the (" $\mathrm{H}$ ", $=\mathrm{H}^{+}+e^{-}$) entering Eq. (2) is different from that of hydrogen in $\mathrm{H}_{2}$. It may be ${ }^{36}$ that the reaction is able to proceed at room temperature because the enzyme feeds hydrogens with a higher chemical potential than in $\mathrm{H}_{2}$ into the reaction in the form of electrons with a high electrochemical potential and/or through the hydrolysis of ATP., ${ }^{47-39}$ If this is the case, it might be possible to produce ammonia by electrolysis of the isolated FeMoco. So far no one has been able to do that, but a first step in this direction has been taken by Pickett et al. $^{25}$ who have have reported that for large enough negative bias, $\mathrm{H}_{2}$ can be produced, showing that the chemical potential of $\left(\mathrm{H}^{+}+e^{-}\right)$in the active site of the enzyme can be raised electrochemically above that of hydrogen in $\mathrm{H}_{2}$. Shilov et $a l .{ }^{40}$ have catalytically reduced acetylene by means of the FeMoco and various amalgams as reductants. In this connection it is also relevant to note that there has been several reports on the protolysis of $\mathrm{N}_{2}$ containing transition metal complexes under strongly reducing conditions. ${ }^{41-43}$

The possibility that we will discuss in the following is whether a process like the one shown in Fig. 2 is possible directly on a metal surface in particular if extra energy is fed into the reaction electrochemically. We are using the DFT calculations to study the question whether the FeMoco model system we consider is unique in letting the process in Fig. 2 go so relatively easily, or whether a similarly facile process is possible at a metal surface. If that is the case, it might be possible to form $\mathrm{NH}_{3}$ at a metal surface, by using it as the cathode in a proton containing electrolyte in the presence of molecular nitrogen.

\section{CALCULATIONAL DETAILS}

The DFT calculations behind the results in Figs. 1 and 2 and the further results to follow are based on a plane-wave expansion of the wave functions, a GGA description of exchange and correlation effects, ${ }^{44,45}$ and ultra soft pseudopotentials $^{46}$ except for $\mathrm{S}$ where a nonlocal soft pseudopotential ${ }^{47}$ is used. Plane waves with kinetic energies up to $25 \mathrm{Ry}$ are used. The self-consistent electron density is determined by iterative diagonalization of the Kohn-Sham Hamiltonian, Fermi-population of the Kohn-Sham states $\left(k_{B} T=0.1 \mathrm{eV}\right)$, and Pulay mixing of the resulting electronic density. ${ }^{48}$ All total energies have been extrapolated to $k_{B} T$ $=0 \mathrm{eV}$.

In the DFT calculations, the $\mathrm{MoFe}_{6} \mathrm{~S}_{9}$ complex is repeated periodically in one direction to give all $\mathrm{Fe}$ and Mo atoms the same coordination number as in the real FeMoco. In the other two directions the system is also repeated periodically but with vacuum in between to avoid interaction effects. A complete structural relaxation to the lowest energy state is performed for each configuration studied. It turns out that the model $\mathrm{MoFe}_{6} \mathrm{~S}_{9}$ complex has bond lengths and angles closely resembling those found experimentally for the FeMoco. ${ }^{27-32}$ For further details of the calculations on the model of the active part of the enzyme, see Ref. 36. The only difference is that in the present paper the obtained densities are used as input for a total energy calculations using the

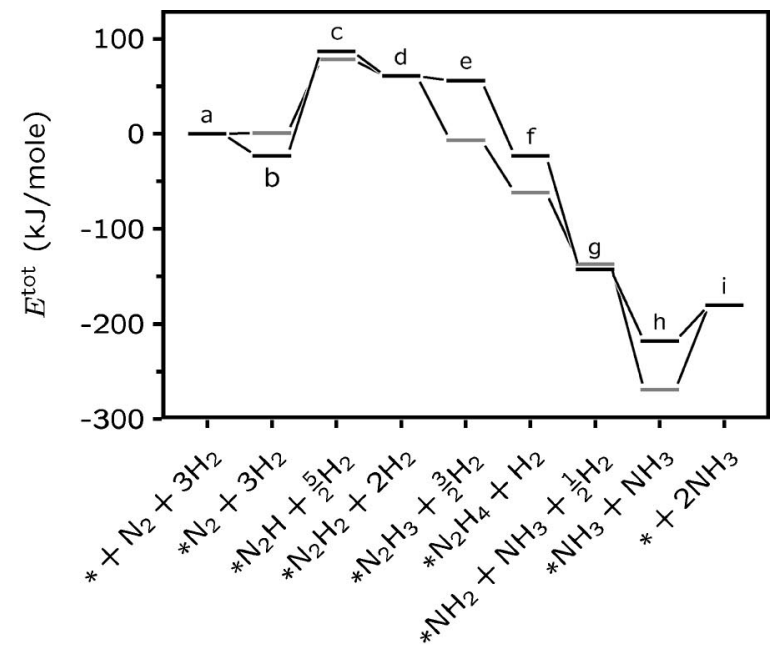

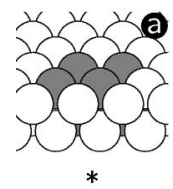
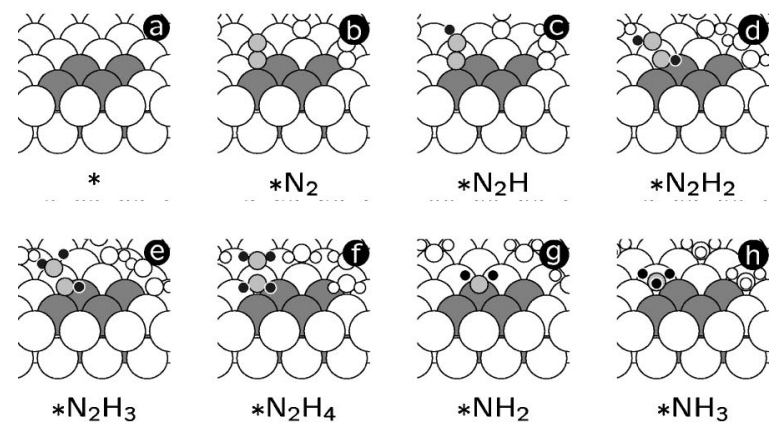

FIG. 3. Energy diagram for the hydrogenation of $\mathrm{N}_{2}$ on the $\mathrm{Ru}(0001)$ surface and on the $\mathrm{MoFe}_{6} \mathrm{~S}_{9}$ complex modeling the FeMoco. In the top panel the binding energies of the most stable intermediates for the adsorption and hydrogenation of $\mathrm{N}_{2}$ are plotted for $\mathrm{Ru}(0001)$ (black bars) and the $\mathrm{MoFe}_{6} \mathrm{~S}_{9}$ complex (gray bars). The total binding energy, $E^{\text {tot }}$, defined in Fig. 1, is relative to the gas phase molecules $\mathrm{H}_{2}(g)$ and $\mathrm{N}_{2}(g)$. The asterisk along the horizontal axis denotes either the $\mathrm{MoFe}_{6} \mathrm{~S}_{9}$ complex in case of the gray bars or the $\mathrm{Ru}(0001)$ surface in case of the black bars. The labels of the black bars refer to the structures of the most stable intermediates for the $\mathrm{Ru}(0001)$ surface shown below the energy diagram. One super cell is gray toned such that $\mathrm{Ru}$ is medium gray, $\mathrm{N}$ is light gray, and $\mathrm{H}$ is black.

slightly more accurate RPBE functional to describe exchange correlation effects. ${ }^{45}$

The metal surface chosen to study the question of a molecular $\mathrm{N}_{2}$ hydrogenation process is the $\mathrm{Ru}(0001)$ surface modeled by a periodic array of two layer slabs separated by the equivalent of five layers of vacuum. An unit cell giving $(2 \times 2)$ periodicity along the surface is used and the corresponding Brillouin zone is sampled by 18 special $k$-points. The two layer slab gives results for $\mathrm{N}$ and $\mathrm{N}_{2}$ adsorption that are within $0.2 \mathrm{eV}$ of the results using 3-6 layers. The remaining computational details are exactly as for the model enzyme. ${ }^{36}$ The adsorbed species were allowed to fully relax, but the substrate atoms were kept fixed at their ideal bulk positions.

\section{GENTLE $\mathrm{N}_{2}$ HYDROGENATION}

In Fig. 3 we investigate the possibility of hydrogenating $\mathrm{N}_{2}$ directly when it is adsorbed on the $\mathrm{Ru}(0001)$ surface. As for the $\mathrm{MoFe}_{6} \mathrm{~S}_{9}$ complex the calculations for the surface have been performed by first adsorbing $\mathrm{N}_{2}$ and then adding 
$\mathrm{H}$ atoms one by one. Each time a new $\mathrm{H}$ atom is added several bindings sites on $\mathrm{N}_{2}$ have been tried in order to find the most stable intermediate. In Fig. 3 we include the structures of the most stable intermediates.

It is clear from Fig. 3 that the most stable intermediates on the $\mathrm{Ru}$ surface are very similar to those found for the model enzyme. In both cases the first hydrogenation step is endothermic. After that the reaction proceeds exothermically until the first ammonia splits off after addition of the fifth hydrogen, Fig. 3(g). Addition of the sixth hydrogen forms adsorbed ammonia Fig. 3(h), which desorbs endothermically, Fig. 3(i).

In agreement with other evidence, ${ }^{49,50}$ our calculations indicate that the transfer of protons to the adsorbed $\mathrm{N}_{2}$ is not associated with significant energy barriers. If we assume this to be the case, the rate limiting step is associated with reaching the state Fig. 2(c) or Fig. 3(c). The small adsorption energy, $E(b)$, gives rise to a low coverage of $\mathrm{N}_{2}$ at the temperatures and pressures of interest here $(300 \mathrm{~K}$ and 1 atm). It is simple to show that due to the low coverage, the rate for the total reaction depends only on $E(c)$ and not on $E(c)-E(b) .{ }^{51}$ The overall activation energy for the total reaction is, therefore, equal to $E(c)$. We find $E(c)$ $=80 \mathrm{~kJ} / \mathrm{mole}$ for the $\mathrm{MoFe}_{6} \mathrm{~S}_{9}$ complex and $E(c)$ $=90 \mathrm{~kJ} / \mathrm{mole}$ for $\mathrm{Ru}(1001)$. As discussed above, when the hydrogen atoms are added in the form of electrons and protons, the barrier may be decreased by changing the electrochemical potential of the electrons.

The calculations do not have an accuracy to predict accurately activation energies, but they strongly indicate that for a sufficiently negative bias the metal surface should in principle allow ammonia production at room temperature and atmospheric pressure. There are of course a number of potential problems in achieving this, the most serious of which may be the competition of the ammonia synthesis with hydrogen evolution. The same is seen in the enzyme process where $\mathrm{H}_{2}$ production also competes with $\mathrm{NH}_{3}$ formation. On the $\mathrm{Ru}$ surface the problem is worse because $\mathrm{H}$ atoms bind stronger than $\mathrm{N}_{2}$ to the surface, while the opposite is true at the active site of the $\mathrm{MoFe}_{6} \mathrm{~S}_{9}$ complex, where $\mathrm{H}$ bound to $\mathrm{Fe}$ is unstable relative to $\mathrm{H}$ on $\mathrm{S}$ or $\mathrm{H}_{2(g)}{ }^{36}$ Perhaps steps which bind $\mathrm{N}_{2}$ significantly stronger than terraces and does not bind $\mathrm{H}$ atoms quite as strongly can act as active sites for this reaction. This may, however, introduce $\mathrm{N}_{2}$ dissociation which would immediately destroy the reactive sites. Alternatively, the Ru surface or other metal surfaces may have to be poisoned by, e.g., sulfur adsorption which both prevents $\mathrm{H}$ adsorption ${ }^{52}$ and $\mathrm{N}_{2}$ dissociation. ${ }^{53}$ In fact, one may view the FeMoco as a Fe cluster passivated by $\mathrm{S}$. In this connection it may be important that the cluster can distort to accommodate the $\mathrm{N}_{2}$, see Fig. 2(a) and 2(b), as pointed out by Somorjai and Borodko. ${ }^{54}$ Yet another possibility is to use a noble metal or a surface alloy adsorbing $\mathrm{H}$ atoms less strongly.

Apart from a negative bias, the requirement for a low temperature ammonia synthesis reaction from $\mathrm{N}_{2}$ is that protons are readily available. This may be accomplished in solution, or by using a proton conductor as the electrolyte. It cannot be excluded that the enzyme has a structure that facilitates the proton transfer particularly well, and that it is difficult to obtain equally good conditions at a metal surface. On the other hand, it is known that even the isolated cofactor can produce $\mathrm{H}_{2},{ }^{25}$ can protonate acetylene, ${ }^{40}$ and binds $\mathrm{CO}$ in much the same way as in the enzyme. ${ }^{26}$

Recently it has been reported that ammonia was produced electrochemically by a Pd catalyst on a proton conducting oxide. ${ }^{55} \mathrm{We}$ suggest that this might have happened by the mechanism discussed here. We note that a reasonably low temperature reaction using $\mathrm{H}_{2}$ as the $\mathrm{H}$ source might even be possible at the surface if $\mathrm{N}_{2}$ dissociation and $\mathrm{H}$ poisoning can be avoided.

\section{SUMMARY}

In summary, we have calculated the most stable intermediates along a reaction path where adsorbed $\mathrm{N}_{2}$ on $\mathrm{Ru}(0001)$ is hydrogenated, and compared the results with the corresponding reaction mechanism previously published for the enzyme nitrogenase. The comparison shows many similarities between the mechanism on these two catalysts. In particular, we find that both reaction mechanism may proceed at low temperature if hydrogen is fed into the reaction in the form of electrons and protons with a higher chemical potential than hydrogen in the form of $\mathrm{H}_{2}$.

\section{ACKNOWLEDGMENTS}

The present work was in part financed by The Danish Research Councils through Grant No. 9501775. The Center for Atomic-scale Materials Physics (CAMP) is sponsored by the Danish National Research Foundation.

${ }^{1} \mathrm{~S}$. R. Tennison, in Catalytic Ammonia Synthesis Fundamentals and Practice, edited by J. R. Jennings (Plenum, New York, 1991), p. 303.

${ }^{2}$ K.-I. Aika and K. Tamura, in Ammonia: Catalysis and Manufacture, edited by A. Nielsen (Springer-Verlag, Berlin, 1995), p. 103.

${ }^{3}$ L. Stryer, Biochemistry, 4 ed. (W. H. Freeman and Company, New York, 1995), p. 714.

${ }^{4}$ B. K. Burgess and D. J. Lowe, Chem. Rev. 96, 2983 (1996).

${ }^{5}$ J. A. Dumesic, H. Topsøe, and M. Boudart, J. Catal. 37, 513 (1975).

${ }^{6}$ N. D. Spencer, R. C. Schoonmaker, and G. A. Somorjai, J. Catal. 74, 129 (1982).

${ }^{7}$ F. Bozso, G. Ertl, M. Grunze, and M. Weiss, J. Catal. 49, 18 (1977).

${ }^{8}$ I. Alstrup, I. Chorkendorff, and S. Ullmann, Z. Phys. Chem. (Leipzig) 198, 123 (1997).

${ }^{9}$ S. Dahl, A. Logadottir, R. C. Egeberg, J. H. Larsen, I. Chorkendorff, E. Törnqvist, and J. K. Nørskov, Phys. Rev. Lett. 83, 1814 (1999).

${ }^{10}$ O. Hinrichsen, F. Rosowski, M. Muhler, and G. Ertl, Chem. Eng. Sci. 51, 1683 (1996).

${ }^{11}$ S. Dahl, P. A. Taylor, E. Törnqvist, and I. Chorkendorff, J. Catal. 178, 679 (1998).

${ }^{12}$ P. Stoltze and J. K. Nørskov, Phys. Rev. Lett. 55, 2502 (1985).

${ }^{13}$ P. Stoltze and J. K. Nørskov, J. Catal. 110, 1 (1988).

${ }^{14}$ M. Bowker, I. Parker, and K. C. Waugh, Surf. Sci. 197, L223 (1988).

${ }^{15}$ L. M. Aparicio and J. A. Dumesic, in Frontiers in Catalysis: Ammonia Synthesis and Beyond, Vol. 1 of Topics in Catalysis, edited by H. Topsøe, M. Boudart, and J. K. Nørskov (Baltzer, Basel, 1994), p. 233.

${ }^{16}$ J. J. Mortensen, L. B. Hansen, B. Hammer, and J. K. Nørskov, J. Catal. 182, 479 (1999).

${ }^{17}$ F. Bozso, G. Ertl, M. Grunze, and M. Weiss, Appl. Surf. Sci. 1, 103 (1977).

${ }^{18}$ J. K. Nørskov and P. Stoltze, Surf. Sci. 189/190, 91 (1987).

${ }^{19}$ M. Mavrikakis, L. B. Hansen, J. J. Mortensen, B. Hammer, and J. K. Nørskov, in Transition State Modeling for Catalysis, Vol. 721 of ACE Symp. Ser., edited by D. G. Truhlar and K. Morokuma (1999), Chap. 19, p. 245 . 
${ }^{20}$ S. J. George, G. A. Ashby, C. W. Wharton, and R. N. F. Thorneley, J. Am. Chem. Soc. 119, 6450 (1997).

${ }^{21}$ H. I. Lee, B. J. Hales, and B. M. Hoffman, J. Am. Chem. Soc. 119, 11395 (1997).

${ }^{22}$ K. L. C. Grönberg, C. A. Gormal, M. C. Durrant, B. E. Smith, and R. A. Henderson, J. Am. Chem. Soc. 120, 10613 (1998).

${ }^{23}$ H.-I. Lee, K. S. Thrasher, D. R. Dean, W. E. Newton, and B. M. Hoffman, Biochemistry 37, 13370 (1998).

${ }^{24}$ L. M. Cameron and B. J. Hales, Biochemistry 37, 9449 (1998).

${ }^{25}$ T. L. Gall, S. K. Ibrahim, C. A. Gormal, B. E. Smith, and C. J. Pickett, Chem. Comm. 9, 773 (1999).

${ }^{26}$ S. K. Ibrahim, K. Vincent, C. A. Gormal, B. E. Smith, S. P. Best, and C. J. Pickett, Chem. Comm. 11, 1019 (1999).

${ }^{27}$ J. B. Howard and D. C. Rees, Chem. Rev. 96, 2965 (1996).

${ }^{28}$ M. K. Chan, J. Kim, and D. C. Rees, Science 260, 792 (1993).

${ }^{29}$ H. I. Liu, A. Filipponi, N. Gavini, B. K. Burgess, B. Hedman, A. DiCicoo, C. R. Natoli, and K. O. Hodgson, J. Am. Chem. Soc. 116, 2418 (1994).

${ }^{30}$ J. Christiansen, R. C. Tittsworth, B. J. Hales, and S. P. Cramer, J. Am. Chem. Soc. 117, 10017 (1995).

${ }^{31}$ J. W. Peters, H. B. Stowell, S. M. Soltis, M. G. Finnegan, M. K. Johnson, and D. C. Rees, Biochemistry 36, 1182 (1997).

${ }^{32}$ I. Harvey, R. W. Strange, R. Schneider, C. A. Gormal, C. D. Garner, S. S. Hasnain, R. L. Richards, and B. E. Smith, Inorg. Chim. Acta 275-276, 150 (1998).

${ }^{33}$ R. N. F. Thorneley and D. J. Lowe, in Molybdenum Enzymes, edited by T. G. Spiro (Wiley-Interscience, New York, 1985), Chap. 5.

${ }^{34}$ I. Dance, Chem. Comm. 2, 165 (1997).

${ }^{35}$ P. E. M. Siegbahn, J. Westerberg, M. Svensson, and R. H. Crabtree, Phys. Chem. B 102, 1615 (1998).

${ }^{36}$ T. H. Rod, B. Hammer, and J. K. Nørskov, Phys. Rev. Lett. 82, 4054 (1999).

${ }^{37}$ W. N. Lanzilotta and L. C. Seefeldt, Biochemistry 36, 12976 (1997).

${ }^{38}$ J. H. Spee, A. F. Arendsen, H. Wassink, S. J. Marritt, W. R. Hagen, and H. Haaker, FEBS Lett. 432, 55 (1998).
${ }^{39}$ J. M. Chan, M. J. Ryle, and L. C. Seefeldt, J. Biol. Chem. 274, 17593 (1999).

${ }^{40}$ T. A. Bazhenova, M. A. Bazhenova, G. N. Petrova, A. K. Shilova, and A. E. Shilov, Russ. Chem. Bull. 47, 861 (1998).

${ }^{41}$ C. J. Pickett and J. Talarmin, Nature (London) 317, 652 (1985).

${ }^{42}$ G. J. Leigh, Acc. Chem. Res. 25, 177 (1992).

${ }^{43}$ T. A. Bazhenova and A. E. Shilov, Coord. Chem. Rev. 144, 69 (1995).

${ }^{44}$ J. P. Perdew, J. A. Chevary, S. H. Vosko, K. A. Jackson, M. R. Pederson, D. J. Singh, and C. Fiolhais, Phys. Rev. B 46, 6671 (1992).

${ }^{45}$ B. Hammer, L. B. Hansen, and J. K. Nørskov, Phys. Rev. B 59, 7413 (1999).

${ }^{46}$ D. Vanderbilt, Phys. Rev. B 41, 7892 (1990).

${ }^{47}$ N. Troullier and J. L. Martins, Phys. Rev. B 43, 1993 (1991).

${ }^{48}$ G. Kresse and J. Furthmüller, Comput. Mater. Sci. 6, 15 (1996).

${ }^{49}$ M. E. Tuckerman, D. Marx, M. L. Klein, and M. Parrinello, Science 275, 817 (1997).

${ }^{50}$ W. W. Cleland, P. A. Frey, and J. A. Gerlt, J. Biol. Chem. 273, 25529 (1998).

${ }^{51}$ The rate at low ammonia pressures is given by $r=2 k \theta_{\mathrm{N}_{2}}$, where the rate constant, $k$, for $b \rightarrow c$ is proportional to $\exp \left(-(E(c)-E(b)) / k_{B} T\right)$. $\theta_{\mathrm{N}_{2}}$ is the degree of $\mathrm{N}_{2}$ coverage, given by a Langmuir isotherm. For low coverage the Langmuir isotherm gives that $\theta_{\mathrm{N}_{2}}$ is proportional to $\exp \left(-E(b) / k_{B} T\right)$. We find, therefore, that $r$ is proportional to $\exp \left(-E(c) / k_{B} T\right)$ for low coverage.

${ }^{52}$ J. A. Schwarz, Surf. Sci. 87, 525 (1979).

${ }^{53}$ J. J. Mortensen, B. Hammer, and J. K. Nørskov, Surf. Sci. 414, 315 (1998).

${ }^{54}$ G. A. Somorjai and Y. Borodko, Catal. Lett. 59, 89 (1999).

${ }^{55}$ G. Marnellos and M. Stoukides, Science 282, 98 (1998).

${ }^{56}$ J. A. Pople and L. A. Curtiss, J. Chem. Phys. 95, 4385 (1991). 